F. Reprod. Fert. (1971) 24, 439-440

\title{
THE EFFECT OF TESTOSTERONE PROPIONATE ON OVARIAN ACTIVITY IN SHEEP
}

\author{
H. M. RADFORD AND A. L. G. WALLAGE
}

CSIRO, Division of Animal Physiology, Ian Clunies Ross Animal Research Laboratory, Prospect, N.S.W., Australia

(Received 6th October 1970)

The experiments reported in this communication were carried out as part of a continuing quest for a simple method of inducing ovulation during anoestrus in the sheep. Although treatment with oestrogen stimulates the release of $\mathbf{L H}$ (Goding, Gatt, Brown, Kaltenbach, Cumming \& Mole, 1969; Radford, Wheatley \& Wallace, 1969), and can induce ovulation during anoestrus (Radford, Wallace \& Wheatley, 1970a), fertilization was not achieved following such treatment (Radford, Wallace \& Wheatley, 1970b). Another approach investigated was stimulation of the release of FSH in the expectation that once this was initiated, release of $\mathbf{L H}$ and ovulation would follow subsequently. Recently Naqvi \& Johnson (1969) reported that testosterone propionate appeared to stimulate both the production and release of FSH in the immature rat, and we now report that a similar response may occur in sheep.

TABLE 1

CLASSIFICATION OF EWES ACGORDING TO STATE OF OVARIES 5 DAYS AFTER INJECTION OF TESTOSTERONE PROPIONATE

\begin{tabular}{|c|c|c|c|c|}
\hline \multirow{3}{*}{$\begin{array}{c}\text { Testosterone } \\
\text { propionate } \\
\text { (mg) }\end{array}$} & \multirow{3}{*}{ No. of ewes } & \multicolumn{3}{|c|}{ No. of ewes with ovaries containing: } \\
\hline & & \multirow{2}{*}{$\begin{array}{c}\text { Recent } \\
\text { corpora lutea* }\end{array}$} & \multicolumn{2}{|c|}{ No recent corpora lutea } \\
\hline & & & $\begin{array}{l}\text { Follicles } \\
>7 \mathrm{~mm}\end{array}$ & $\begin{array}{r}\text { Follicles } \\
<7 \mathrm{~mm}\end{array}$ \\
\hline 0 & 14 & - & - & 14 \\
\hline (oin ony) & 3 & 3 & - & - \\
\hline 5 & 10 & 5 & 4 & 1 \\
\hline 10 & 5 & 2 & 1 & 2 \\
\hline & 10 & & 3 & 4 \\
\hline
\end{tabular}

* Estimated to be 1 to 2 days old.

Anoestrous Border Leicester ewes were injected i.m. with $0,1,5,10$, or $25 \mathrm{mg}$ testosterone propionate in peanut oil, and the ovaries examined at laparotomy 5 days later. The results, which are set out in Table 1, indicate that the testosterone propionate caused ovarian stimulation at all dose levels, but with a suggestion that greater stimulation occurred at the lower end of the range of doses tested. 
The precise manner in which testosterone propionate acted to cause such stimulation remains to be determined but it seems clear that considerable release of FSH must have occurred. This would be expected to cause not only increased follicular growth but also increased production of oestrogen, which, in turn, would promote the release of $\mathrm{LH}$.

The argument that the induction of ovulation by testosterone propionate is mediated by way of ovarian oestrogen production is supported by the following results. Five ovariectomized ewes were injected i.m. with $5 \mathrm{mg}$ testosterone propionate and jugular vein blood samples were collected at 4-hr intervals for 4 days. As determined by radioimmunoassay (Wheatley \& Radford, 1969) there was no change in circulatory LH during this period.

A direct measure of the effect of testosterone propionate on pituitary FSH content was obtained by bioassay (Steelman \& Pohley, 1953) of the pituitaries from two ovariectomized ewes killed 3 days after $5 \mathrm{mg}$ testosterone propionate was injected i.m., and from two untreated ovariectomized ewes. The two pituitaries from each group were pooled for assay. Higher FSH levels $(450 \mu \mathrm{g} / \mathrm{g}$ pituitary tissue) were found in the testosterone propionate treated ewes than in the control animals ( $300 \mu \mathrm{g} / \mathrm{g}$ pituitary tissue). The increased levels in the pituitaries from the testosterone propionate-treated ewes could be due either to increased synthesis accompanying release into the circulation, as suggested by Naqvi \& Johnson (1969) or to increased storage of hormone before release.

\section{REFERENCES}

Goding, J. R., Gatt, K. J., Brown, J. M., Kaltenbach, C. G., Gumming, I. A. \& Mole, B. J. (1969) Radioimmunoassay for ovine luteinizing hormone. Secretion of luteinizing hormone during estrus and following estrogen administration in the sheep. Endocrinology, 85, 133.

NAQVi, R. H. \& Johnson, D. C. (1969) Increased production of follicle-stimulating hormone in immature female rats by a single injection of androgen or oestrogen. $\mathcal{F}$. Endocr. 45, 29.

RAdFord, H. M., WAllace, A. L. C. \& WheAtley, I. S. (1970a) Lh release, ovulation and oestrus following the treatment of anoestrous ewes with ovarian steroids. F. Reprod. Fert. 21, 371.

Radford, H. M., Wallace, A. L. C. \& Wheatley, I. S. (1970b) Steroid-induced gonadotrophin release in the ewe. (Abstract). F. Reprod. Fert. 24, 147.

Radford, H. M., Wheatley, I. S. \& Wallace, A. L. C. (1969) The effects of oestradiol benzoate and progesterone on secretion of luteinizing hormone in the ovariectomized ewe. F. Endocr. 44, 135.

Strelman, S. L. \& Pohley, F. M. (1953) Assay of the follicle stimulating hormone based on the augmentation with human chorionic gondadotropin. Endocrinology, 53, 604.

WhEATLEY, I. S. \& RADFORD, H. M. (1969) Luteinizing hormone secretion during the oestrous cycle of the ewe as determined by radio-immunoassay. F. Reprod. Fert. 19, 211. 